Reprod. Nutr. Dévelop., 1983, 23 (1), 137-144.

\title{
Pancreatic hydrolases in cold-induced hyperphagia of rats fed a low or high-fat diet
}

\author{
Anik GIRARD-GLOBA, Geneviève BOURDEL
}

Centre de Recherches sur la Nutrition du C.N.R.S., 9, rue J.-Hetzel, 92190 Meudon-Bellevue, France.

Summary. Rats fed either a low (2 p. 100) or high (40 p. 100)-fat diet were exposed to 22 or $5^{\circ} \mathrm{C}$. The resulting hyperphagia adequately compensated energy losses as judged from body weight. The cold-induced hyperphagia was accompanied by a non-parallel increase in pancreatic hydrolases. Amylase and lipase were not increased above the adaptive levels they had respectively reached in the heat with a high-starch or high-lipid diet. Chymotrypsinogen, on the contrary, responded to increased intake of both diets. It also responded to the higher protein concentration in the high-fat diet caused by isocaloric replacement of starch by fat. Colipase varied independently of lipase and was increased additively by fat and protein intakes. Consequently, although limiting for lipase in the warm, colipase rose to a 1:1 ratio in the cold. Increased intake had a consistent pleiotropic effect evidenced by an increase of amylase with the high-fat diet and of lipase with the low-fat diet. The net effect was a significant increase in the lipid-digesting potential of the organism of lipid-fed animals upon exposure to cold, while the starch-digesting potential remained unaffected in starch-fed animals.

\section{Introduction.}

Body temperature of rats exposed to cold is maintained by an increase in heat production through the progressive development of non-shivering thermogenesis (Hart, Heroux and Depocas, 1956). The needs of this heat production are met by an increase in food consumption which entails increased digestive processes. The cold-adapted rat therefore provides an interesting model for the study of pancreatic adjustment to quantitative variation in various nutriments without the modifications in their dietary proportions which are necessary when animals are fed under isocaloric conditions. Lipid-rich diets also have the appreciable advantage of being highly palatable to the rat and of offering more calories in a smaller volume. The adaptive capacities of lipase being relatively limited (Saraux et al., 1982), it was interesting to compare the effect of low and high-fat diets on the digestive capacity of the pancreas, particularly taking account of colipase which was shown to respond differently than lipase to nutritional stimuli (Saraux et al., 1982). In a study of CCK-induced secretion in anesthetized rats or 
perfused pancreata, Harada and Kanno (1976) and Habara et al. (1979) found that the proportion of amylase in the secreted juice was decreased by exposure to cold, but they could not find any difference in the actual amount of enzymes secreted. For this reason, we thought it would be more significant to determine the gross pancreatic contents of each hydrolase at the time of maximal accumulation, i.e. during the resting period (Girard-Globa et al., 1980).

\section{Material and methods}

We used male Sprague-Dawley rats weighing $200 \mathrm{~g}$ at the beginning of the experimental period. They were housed in individual cages under controlled lighting (lights-on 07:00 to 19:00 h) and were acclimated either to 22 or to $5^{\circ} \mathrm{C}$. Two diets were compared at each temperature : a high-lipid diet containing 42.5 p. 100 lard and a low-lipid diet containing 2.5 p. 100 lard supplemented with 0.4 p. 100 sunflower oil to provide the necessary unsaturated fatty acids (table 1). The experimental period lasted 8 weeks and food intake and weight gain were recorded biweekly. At the end of this period 10 animals in each group were exsanguinated by aortic puncture under light ether anesthesia at 13:00 h, and their pancreata were rapidly excised and frozen at $-40^{\circ} \mathrm{C}$.

TABLE 1

Experimental diets (per cent by weight)

\begin{tabular}{|c|c|c|}
\hline & Low-Fat & High-Fat \\
\hline Casein & 12.5 & 33 \\
\hline$\ldots \ldots \ldots \ldots$ & 2.5 & 42.5 \\
\hline 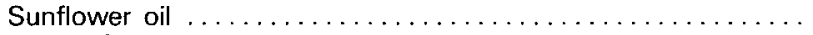 & 0.4 & 0.4 \\
\hline 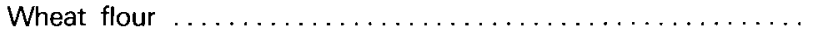 & 77.1 & 9.6 \\
\hline$\ldots \ldots \ldots \ldots \ldots \ldots \ldots \ldots$ & 2.0 & 3.0 \\
\hline Vitamin mix. $\left({ }^{1}\right)$ & 2.2 & 3.3 \\
\hline Salt mix. $\left({ }^{2}\right)$ & 4.0 & 6.0 \\
\hline Calories: Protein & 33.2 & 34.0 \\
\hline
\end{tabular}

(1) Vitamin fortication mixture $\mathrm{NBC}$, Cleveland, $\mathrm{OH}$.

(2) Wesson type salt mix., NBC, Cleveland, $\mathrm{OH}$.

For enzyme determination, the tissue was homogenized with 10 volumes of distilled water in a Potter Elvejehm-type grinder. Amylase was determined by the Dahlquist procedure (Dahlquist, 1962). Chymotrypsinogen was activated with trypsin $(2 \mathrm{mg} / \mathrm{ml})$ and assayed with the synthetic substrate acetyl tyrosine ethyl ester (ATEE ; Sigma) (Hummel, 1959). Lipase was assayed essentially as described by Rathelot et al. (1975) at $\mathrm{pH} 9$ and $28^{\circ} \mathrm{C}$ on an emulsified triolein substrate stabilized by 10 p. 100 gum arabic containing $22 \mathrm{mM}$ glycocholate (Merck), $125 \mathrm{mM} \mathrm{NaCl}$ and $25 \mathrm{mM} \mathrm{CaCl}_{2}$ (final concentrations). The production of fatty acids was titrated by $20 \mathrm{mM} \mathrm{NaOH}$ in a pH stat (Metrohm) in the presence of excess crude exogenous colipase. Colipase was determined by its capacity to restore activity to an exogenous supply of purified lipase in the presence of bile 
salts after destroying the activity of endogenous lipase in the sample by acidification to $\mathrm{pH} 2$ (Ouagued et al., 1980). Leucine transaminase was assayed in the manner described by Ichihara and Koyama (1966). Protein was determined by the Lowry procedure (Lowry et al., 1951).

\section{Results and discussion.}

The animals adapted readily to cold and gained weight regularly (table 2). Caloric intake was independent of the diet (table 2) and controlled by ambient temperature. It was increased 50 p. 100 by exposure to cold. Since the protein : calorie ratio was the same in the two diets, protein intake, the same at both temperatures, was also increased 50 p. 100 by cold exposure. In spite of a similar caloric intake, low-fat fed rats gained significantly less weight at $5^{\circ} \mathrm{C}$ than highfat fed rats at the same temperature, and despite caloric adjustment of intake they also gained less than their controls at $22{ }^{\circ} \mathrm{C}$ (table 2). This can be attributed in part to the metabolic expenditure entailed in the conversion of carbohydrates to fatty acids, necessary for heat production by brown adipose tissue. As will be seen from our results, it might also be due to less efficient digestive capacity.

Contrary to what has been reported by others (Harada et al., 1976), the pancreas was not enlarged by either the cold-induced hyperphagia or the fat feeding (table 3). Protein concentrations, however, were significantly higher $(P<0.01)$

TABLE 2

Daily protein and caloric intake and body weight gain

\begin{tabular}{lcccc} 
& \multicolumn{2}{c}{ Low-Fat } & \multicolumn{2}{c}{ High-Fat } \\
\cline { 2 - 5 } & $22^{\circ} \mathrm{C}$ & $5^{\circ} \mathrm{C}$ & $22^{\circ} \mathrm{C}$ & $5^{\circ} \mathrm{C}$ \\
\hline Calories & 63.4 & 95.8 & 59.5 & 96.3 \\
Protein (g) & 3.3 & 5.1 & 3.3 & 5.4 \\
\hline Weight gain & $3.7^{\mathrm{a}}$ & $3.1^{\mathrm{b}}$ & $4.8^{\mathrm{c}}$ & $3.7^{\mathrm{a}}$ \\
(g/day) & \pm 0.1 & \pm 0.2 & \pm 0.2 & \pm 0.1 \\
\hline
\end{tabular}

Mean \pm SEM.

Values having the same superscript are not significantly different.

TABLE 3

Weight and protein content of the pancreas

\begin{tabular}{|c|c|c|c|c|}
\hline & \multicolumn{2}{|c|}{ Low-Fat } & \multicolumn{2}{|c|}{ High-Fat } \\
\hline & $22{ }^{\circ} \mathrm{C}$ & $5^{\circ} \mathrm{C}$ & $22{ }^{\circ} \mathrm{C}$ & $5^{\circ} \mathrm{C}$ \\
\hline $\begin{array}{l}\text { Weight }(\mathrm{g}) \\
\text { Protein }(\mathrm{mg} / \mathrm{g})\end{array}$ & $\begin{array}{l}0.946 \pm .082^{\mathrm{a}} \\
153.5 \pm 2.5^{\mathrm{a}}\end{array}$ & $\begin{array}{l}1.021 \pm .040^{\mathrm{a}} \\
177.4 \pm 5.8^{\mathrm{b}}\end{array}$ & $\begin{array}{l}1.087 \pm .051^{\mathrm{a}} \\
160.1 \pm 3.6^{\mathrm{a}}\end{array}$ & $\begin{array}{l}1.036 \pm .061^{\mathrm{a}} \\
172.4 \pm 4.6^{\mathrm{b}}\end{array}$ \\
\hline Leucine transaminase & $54.53 \pm 2.99^{a}$ & $\begin{array}{c}64.24 \pm 4.25^{b} \\
(p \quad 0.05)\end{array}$ & $52.50 \pm 5.19^{a}$ & $\begin{array}{c}78.26 \pm 4.59^{b} \\
(p \quad 0.01)\end{array}$ \\
\hline
\end{tabular}

Mean \pm SEM.

Values having the same superscript are not significantly different. 
in the cold-exposed rats of both dietary groups (table 3). Since the animals were killed at the time of maximal accumulation (Girard-Globa et al., 1980), this probably reflects an increase in hydrolase content rather than an increase in structural protein. Indeed, as seen on table 4, hydrolase content was greater in coldacclimated rats. Chymotrypsinogen was increased in the cold by 82 p. 100 with the low-fat diet and by 45 p. 100 with the high-fat one, in keeping with the 50 to 60 p. 100 increase in protein intake (table 2). However, it should be noted that, despite the ingestion of identical amounts of protein, the chymotrypsinogen content was significantly higher in fat-fed rats at the same temperature. Dietary lipid content has no influence on chymotrypsinogen accumulation (DeschodtLanckman et al., 1971 and our own unpublished data). But it has been shown recently that the production of chymotrypsinogen is directly related to the concentration of ingested protein as well as to the actual amount of it (Bourdel, 1982). Since fat is twice as energetic as starch, the concentration of protein in the present study was twice higher in the fat-fed diets in order to obtain identical protein : calorie ratios. It is most likely, therefore, that the rise in chymotrypsinogen in fat-fed rats at both ambient and cold temperatures can be attributed to a higher concentration of protein in the diet. Moreover, it should be noted that in fat-fed, cold-adapted rats the effects of increased protein intake and increased concentration in the diet were additive, suggesting that the two parameters act through distinct pathways.

Amylase was already high in the low-fat rats at $22{ }^{\circ} \mathrm{C}$ and was not increased by cold-induced hyperphagia in spite of the sizable supplement of ingested starch. Similarly, lipase was not augmented in fat-fed animals in the cold. This lack of response to an increased supply of specific substrate shows that a maximum had already been reached and that the adaptive capacity of the two hydrolases was limited. Suprisingly, hyperphagia significantly increased the hydrolase not already stimulated by the diet : lipase in the low-fat fed animals and amylase in the high-fat fed were twice higher in the cold. Considering the very small amounts of fat and starch ingested respectively by the animals in the two groups, and knowing that shifting from 1 to $12 \mathrm{p}$. 100 lipid in the diet causes no increase in lipase (Lavau, Bazin and Herzog, 1974), this increase of hydrolase cannot be considered as a specific adaptation to increased substrate supply but rather as the pleiotropic effect of increased protein supply. In the course of pre-

TABLE 4

Enzyme contents (U per pancreas)

\begin{tabular}{|c|c|c|c|c|c|}
\hline \multirow{6}{*}{$\begin{array}{l}\text { Chymotrypsinogen } \\
\text { Amylase } \\
\text { Lipase (total) } \\
\text { Colipase }\end{array}$} & \multicolumn{2}{|c|}{ Low-Fat } & \multicolumn{3}{|c|}{ High-Fat } \\
\hline & \multirow{2}{*}{$\frac{22^{\circ} \mathrm{C}}{2608+227}$} & $5^{\circ} \mathrm{C}$ & \multicolumn{2}{|c|}{$22{ }^{\circ} \mathrm{C}$} & $5^{\circ} \mathrm{C}$ \\
\hline & & $4762 \pm$ & $4375 \pm$ & 369 & $6347 \pm$ \\
\hline & $9908 \pm 897$ & $10738 \pm$ & $2687 \pm$ & 230 & $4568 \pm 410$ \\
\hline & $5984 \pm 516$ & $10599 \pm$ & $16787 \pm$ & 1176 & $17353 \pm 1117$ \\
\hline & $4443 \pm 453$ & $10689 \pm 1711$ & $10108 \pm$ & 1536 & $16746 \pm 1754$ \\
\hline Colipase : Lipase & $0.75 \pm 0.06$ & $0.97 \pm 0.07$ & $0.67 \pm$ & 0.03 & $0.96 \pm 0.07$ \\
\hline
\end{tabular}


vious experiments we pointed out the non-specific sensitivity of amylase and lipase to protein supply. Not only are both hydrolases very slow to adapt when protein supply is limited, but raising protein concentrations to $45 \mathrm{p}$. 100 of the diet increases amylase as much as it does chymotrypsinogen, despite a reduction in the amount of starch ingested (Lavau, Bazin and Herzog, 1974). In the present experiment, this pleiotropic effect of protein is shown to be operative only when the adaptive response is not fully expressed. In other words, adaptive response and pleiotropic effect are not additive.

Colipase, a cofactor of lipase (Maylie et al., 1971 ; Borgström and Erlanson, 1971) rescinding the inhibition of that enzyme by bile salts in the digestive tract, did not vary in strict parallel with lipase. This cofactor has the property of being more sensitive to protein intake than to lipids and can be fully expressed even in the absence of dietary lipids (Saraux et al., 1982). It responds to lipids when protein supply is supraoptimal which was the case in our experiment. Thus, at both 22 and $5{ }^{\circ} \mathrm{C}$ colipase was higher in the fat-fed rats. However, while lipase was already maximally stimulated by the high-fat diet at $22^{\circ} \mathrm{C}$, colipase, which was not, was further increased by cold-induced hyperphagia. The consequence of this difference in behaviour between lipase and colipase is illustrated by the ratios of the hydrolase to its cofactor (table 4). In both dietary groups, colipase was limiting for lipase at $22{ }^{\circ} \mathrm{C}$ (ratio $<1$ ). Thus, since colipase acts in a $1: 1$ ratio with lipase (Borgström and Erlanson, 1973), physiological activity represented only 75 and 67 p. 100 of total potential activity in the low and high-fat groups, respectively. In contrast, in the cold-adapted rats potential activity was totally expressible since colipase was not limiting.

We conclude that the pancreas does not respond to hyperphagia by simply stepping up its hydrolase production. Lipase and amylase adaptation is limited. Since the animals gained weight to almost the same extent in the cold as in the warm, it is likely that hydrolase supply was not a limiting factor of digestion but that it might, for instance, participate in the slight limitation of growth found in starch-fed, cold-adapted rats. The lack of increase of lipase is compensated for by a more ample supply of colipase. This limitation might have been attributed to the inability of the pancreas to synthesize more enzyme-protein, if non-specific stimulation of lipase and amylase.in starch-fed and fat-fed rats, respectively, had not been observed. As it stands, it is more likely that general synthetic capacity of pancreas is increased, messenger RNA being read more efficiently. However, it seems that some messengers, such as those of amylase and lipase, can only be produced in limited amounts or are less efficiently read.

Since it is not really known how the pancreas adapts to hyperphagia other than by a series of specific substrate-induced increases, we attemped to evaluate possible metabolic adaptation to conditions of stimulated production by determining leucine transaminase (EC 2.6.1.6). The pancreas and stomach are organs in which branched-chain amino acids are most actively transaminated (Ichihara, Noda and Goto, 1975). The parallelism with oxidative capacity suggests that transamination is the first step of an efficient energy-producing mechanism (Ichihara, Noda and Goto, 1975), branched amino acids yielding ATP more efficiently than others by increasing the 'acetyl CoA pool' entering the citric cycle (Krebs, 
1964). As shown in table 3, leucine transaminase activity was increased by exposure to cold with both types of diet but to a greater extent with the high-fat one. In a separate experiment we found that doubling the protein intake had no effect on pancreatic leucine transaminase activity when the energetic nutrient was starch, but resulted in an 80 p. 100 increase in the presence of fat (unpublished results). The results presented here are in keeping with this observation and suggest that the increased energy need due to hyperphagic stimulation of hydrolase production is met partly by amino acid transamination land subsequent oxidation), even when the energetic nutriment is lipid ; this implies that, under conditions of stimulated thermogenesis, fatty acid utilization is not favored at the pancreatic level.

Exposure to cold triggers a number of neurohumoral regulatory responses aimed mostly at increasing heat production and reducing heat expenditure. Hyperphagia is one of the most obvious components of this metabolic adjustment and certainly the preponderant factor in the modified composition of exocrine pancreatic secretion. Our results show however that the changes in pancreatic enzyme composition are not solely adaptive sensu stricto because increased ingestion of a specific nutrient did not systematically induce an increase in the corresponding hydrolase. Other inducing pathways would certainly be worth investigating. For instance, the fact that chymotrypsinogen responds to the concentration of protein as well as to the amount of it implies the intervention of a neural or hormonal mechanism of gastroduodenal origin, which could also be triggered by signals of a more peripheral type. Likewise, the accumulation of amylase in fat-fed rats and of lipase in carbohydrate-fed rats kept in the cold could be argued to result from a net stimulation of enzyme production due to neuro-humoral factors linked with the increase in sympathetic tonus. Although much is now known regarding the adaptation of the composition of exocrine pancreatic secretion to food composition, much still has to be learned about more discrete regulations by other factors which might also be involved in adaptation to cold. Combining the use of pharmacologically neuro-active substances and cold exposure could provide a useful insight into some of these mechanisms.

Reçu en mai 1982 Accepté en septembre 1982.

Acknow/edgements. - The authors wish to acknowledge the able technical assistance of Marguerite Forestier, Betty Gouhot and Dominique Vacher and the secretarial contribution of Suzanne Seige.

Résumé. Hydrolases pancréatiques du Rat rendu hyperphagique par l'exposition au froid.

Des rats recevant un régime soit pauvre ( 2 p. 100) soit riche $(40$ p. 100) en lipides, ont été exposés à $22{ }^{\circ} \mathrm{C}$ ou $5{ }^{\circ} \mathrm{C}$. Le maintien du poids corporel montre que l'augmentation des pertes d'énergies a été compensée par l'hyperphagie. L'hyperphagie au froid s'est accompagnée d'une augmentation non parallèle des hydrolases pancréatiques. L'amylase et la lipase n'ont pas augmenté au-delà de leurs niveaux adaptatifs respectifs obtenus au chaud avec le régime amidon ou lipide. Par contre, le chymotrypsinogène répond à l'aug- 
mentation de l'ingéré. II est également augmenté par l'augmentation de la concentration en protéines résultant du remplacement isocalorique de l'amidon par les lipides. La colipase varie indépendamment de la lipase et est augmentée de façon additive à la fois par l'ingéré lipidique et protéique. Ainsi, bien qu'en quantité limitante par rapport à la lipase au chaud, elle atteint un rapport de 1 au froid. L'hyperphagie exerce un effet pléiotropique qui se traduit par une élévation de l'amylase en régime lipidique et de la lipase en régime amidon. L'exposition au froid provoque donc une élévation du potentiel de digestion lipidique sans affecter le potentiel de digestion amylacée.

\section{Références}

BORGSTRÖM B., ERLANSON C., 1971. Pancreatic juice colipase : physiological importance. Biochim. biophys. Acta, 242, 509-513.

BORGSTRÖM B., ERLANSON C., 1973. Pancreatic lipase and colipase. Interactions and effects of bile salts and other detergents Eur. J. Biochem., 37, 60-68.

BOURDEL G., 1982. Effect of separate feeding of proteins and lipids on pancreatic adaptation in the rat. Am. J. Physiol. (To be published).

DAHLSOUIST A., 1962. A method for the determination of amylase in intestinal contents. Scand. J. clin. Lab. Invest., 14, 145-151.

DESCHODT-LANCKMAN M., ROBBERECHT P., CAMUS J., CHRISTOPHE J., 1971. Short-term adaptation of pancreatic hydrolases to nutritional and physiological stimuli in adult rats. Biochimie, 53, 789-796.

GIRARD-GLOBA A., BOURDEL G., LARDEUX B., 1980. Regulation of protein synthesis in the rat pancreas by amount and timing of dietary protein. J. Nutr., 110, 1380-1390.

HABARA Y., KANNO T., SATTO A., 1979. Cold acclimation in the secretory response of the isolated exocrine pancreas of the rat. J. Physiol, London, 293, 447-456.

HARADA A., KANNO T., 1976. Progressive enhancement in the secretory functions of the digestive system of the rat. J. Physiol., London, 260, 629-645.

HART J. S., HEROUX O., DEPOCAS F., 1956. Cold acclimation and the electromyogram of unanesthetized rats. J. appl. Physiol., 9, 404-408.

HUMMEL B. C. W., 1959. A modified spectrophotometric determination of chymotrypsin, trypsin and thrombin. Can. J. Biochem. Physiol., 37, 1393-1399.

ICHIHARA A., KOYAMA E., 1966. Transaminase of branched chain amino acids. I. Branched chain amino acids- $\alpha$ ketoglutarate transaminase. J. Biochem., 59, 160-169.

ICHIHARA A., NODA C., GOTO M., 1975. Transaminase of branched chain amino acids. X. High activity in stomach and pancreas. Bioch. biophys. Res. Com., 67, 1313-1318.

KREBS H. A., 1964. The metabolic fate of amino-acids. In MUNRO H. N., ALLISON J. B. Mammalian protein metabolism. Vol. I, 125-176, Acad. Press., N.Y.

LAVAU M., BAZIN R., HERZOG J., 1974. Comparative effects of oral and parenteral feeding on pancreatic enzymes in the rat. $J$. Nutr., 104, 1432-1437.

LOWRY O. H., ROSEBROUGH N. J., FARR A. L., RANDALL R. J., 1951. Protein measurement with the Folin phenol reagent. J. biol. Chem., 193, 265-275.

MAYLIE M. F., CHARLES M., GACHE C., DESNUELLE P., 1971. Isolation and partial identification of a pancreatic colipase. Biochim. biophys. Acta, 229, 286-289.

OUAGUED M., SARAUX B., GIRARD-GLOBA A., BOURDEL G., 1980. Differential regulation of lipase and colipase in the rat pancreas by dietary fat and proteins. J. Nutr., 110, 2302-2309.

RATHELOT J. R., JULIEN R., CANIONI P., COEROLI C., SARDA L., 1975. Studies on the effects of bile salts and colipase on enzymes lipolysis. Improved method. For the determination of pancreatic lipase and colipase. Biochimie, 57, 1117-1122.

SARAUX B., GIRARD-GLOBA A., OUAGUED M., VACHER D., 1982. Response of the exocrine pancreas to quantitative and qualitative variations in dietary lipids. Am. J. Physiol., 243, G 10-15. 